\title{
Different Kinds of Paraneoplastic Syndromes in Childhood Neuroblastoma
}

\author{
Yu-tong Zhang ${ }^{1}$; Li-hua Feng $^{2}$; Zhen Zhang ${ }^{3}$; Xiao-dan Zhong ${ }^{1}$; Jian Chang ${ }^{1, *}$ \\ ${ }^{1}$ Department of Pediatric Hematology and Oncology, First Hospital of Jilin University, Changchun, China \\ ${ }^{2}$ Department of Obstetrics and Gynecology, First Hospital of jilin University, Changchun, China \\ ${ }^{3}$ Department of Pediatric Intensive Care Unit, First Hospital of jilin University, Changchun, China \\ ${ }^{*}$ Corresponding author: Jian Chang, 71 Xinmin Street, Department of Pediatric Hematology and Oncology, the First Hospital of jilin University, Changchun 130021, Jilin, China. Tel: \\ +86-43188782979, E-mail: zhanglaodi@163.com
}

Received: May 18, 2014; Revised: December 12, 2014; Accepted: December 30, 2014

\begin{abstract}
Background: Clinical presentations of paraneoplastic syndromes in neuroblastoma may multiply. Review of the clinical data and the literature on this syndrome may help in the diagnosis of neuroblastoma.

Objectives: In order to make more accurate diagnosis, we reviewed the clinical data and the literature on this syndrome.

Patients and Methods: Between April 2007 and April 2012, 68 children were diagnosed with neuroblastoma or ganglioneuroblastoma in our institution, 9 of which presented exclusively with paraneoplastic syndromes and were not treated with chemotherapy prior to diagnosis. After the diagnosis, all patients received chemotherapy and operation on NB97 protocol.

Results: Among 68 pediatric patients with neuroblastoma or ganglioneuroblastoma, 4 (5.9\%) patients suffered from neurological complications at diagnosis, $2(2.9 \%)$ patients had digestive tract disorders, $2(2.9 \%)$ patients had immune diseases, and $1(1.5 \%)$ suffered from hematological disorder (without bone marrow involvement). All paraneoplastic syndrome patients achieved complete remission on paraneoplastic syndrome before completion of chemotherapy.

Conclusions: Neuroblastoma may present with a range of non-specific neurologic symptoms in addition to the well-known opsoclonusmyoclonus syndrome and cerebellar ataxia. In any case, the presence of unexplained neurologic manifestations and other common clinical presentations such as rash, constipation, diarrhea, and especially immune disorders in an otherwise healthy child had raised the possibility of paraneoplastic syndrome due to the presence of an undiagnosed tumor.
\end{abstract}

Keywords: Paraneoplastic Syndromes; Neuroblastoma; Child; Ganglioneuroblastoma; Nervous System Diseases

\section{Background}

A variety of paraneoplastic syndromes, the majority of neurological complications, are occurring in timely association with neuroblastoma. Opsoclonus-myoclonus syndrome (OMS), and cerebellar ataxia are the most common paraneoplastic syndromes considered to be paraneoplastic neurologic disorders (PNDs) (1). Kerner-Morrison syndrome is another typical paraneoplastic syndrome. However, clinical presentations of paraneoplastic syndromes may be multiple. Early diagnosis of these syndromes maximizes likelihood of the treatment of the tumor along with the absence of the neurologic manifestations. Within the last 5 years, 68 children were diagnosed with neuroblastoma in our institution. 9 of them presented exclusively with paraneoplastic syndromes involving various organs or systems, some of which were recognized as rare paraneoplastic syndromes. Initially, these patients were misdiagnosed with other diseases and they were treated inappropriately.

\section{Objectives}

In order to make more accurate diagnosis, we reviewed the clinical data and the literature on this syndrome.

\section{Patients and Methods}

Between April 2007 and April 2012, 68 children were diagnosed with neuroblastoma or ganglioneuroblastoma in our institution, 9 of which presented exclusively with paraneoplastic syndromes and had not received chemotherapy before diagnosis. After collecting the patients' clinical records and having reviewed the literature on pediatric neuroblastoma cases that coincided with paraneoplastic syndrome, further understanding of the phenomena was reached. Following diagnosis, all patients received chemotherapy and operation on NB97 protocol.

\section{Results}

At the time of diagnosis, among 68 pediatric patients with neuroblastoma or ganglioneuroblastoma, 4 (5.9\%) patients suffered from neurological complications at diagnosis, 2 (2.9\%) patients had digestive tract disorders, 2 (2.9\%) patients had immune diseases, and 1 (1.5\%) suffered hematological disorder (without bone marrow involvement). Neurological complications were the most common ones, which were followed by digestive and immune diseases. Six patients experienced misdiagnosis and received treatments including gammaglobulin and/

Copyright (C) 2015, Growth \& Development Research Center. This is an open-access article distributed under the terms of the Creative Commons Attribution-NonCommercial 4.0 International License (http://creativecommons.org/licenses/by-nc/4.0/) which permits copy and redistribute the material just in noncommercial usages, provided the original work is properly cited. 
or prednisone/dexamethasone. After chemotherapy and operation, 5 patients achieved complete remission and all 4 patients with PNDs achieved partial response after a median time of 4 months on paraneoplastic syndrome. All patients achieved complete remission of paraneoplastic syndrome before completion of chemotherapy. Among the 9 patients, one (11.1\%) patient died during treatment. Eight (89.9\%) patients continued living for 24 to 39 months. The median follow up duration for these patients was $2.08 \pm 0.929$ (95\% CI, 1.95-3.12) years. The two years event free survival was $77.8 \%$, the two years overall survival was $88.9 \%$. The characteristics of the 9 patients are shown in Table 1.

\section{Discussion}

Paraneoplastic syndrome is defined as a dysfunction of organ systems caused by the remote humoral effects of a tumor and not by local effects or metastases (2). Neurological disorders are known as the most common paraneoplastic syndromes in patients with neuroblastoma. The highest frequency is opsoclpnus-myoclonus syndrome (OMS) (3). OMS has been observed in up to $4 \%$ of patients with neuroblastoma (1). Until now, various clinical cohort studies have shown different rates of neurological paraneoplastic syndromes. One such study claims that it could reach up to $40 \%$ (3), while it was reported $68 \%$ by Chu et al. (4). In our study, the rate of neurological complications was 5.9\%. Apart from OMS, pediatric patients with neuroblastoma have presented with other paraneoplastic neurologic disorders, which include Lambert-Eaton myasthenic syndrome (5), encephalomyelitis (6), cerebellar ataxia (7), and hypothalamic syndrome (1). Among the 9 patients who presented with paraneoplastic syndromes in our study, 4 (5.9\%) had neurological complications, the typical paraneoplastic syndrome was cerebellar ataxia, besides that, myalgia, motor dysfunction of lower extremities and monoplegia of the lower extremity were also seen. Why are paraneoplastic syndromes coinciding with neuroblastoma directly affecting the neurologic system? A variety of autoantibodies have been reported, particularly anti-Hu antibody, in neuroblastoma patients with paraneoplastic syndromes. Histochemically, it has been identified that the anti-Hu antibody reacts with nuclei of neurons throughout the central nervous system (8). OMS was first recognized as a possible remote effect of neuroblastoma by Solomon and Chutorian in 1968 (9). Since then, other neurological signs and syndromes, such as seizures, choreoathetosis, and peripheral neuropathies, have also been described as remote effects of neuroblastoma $(10,11)$.

In our cases, the presence of serum and cerebrospinal fluid (CSF) anti-Hu antibody was associated with complications including cerebellar ataxia, monoplegia of the lower extremity, constipation, and diarrhea. Even though, the initial presentation, in patient 2 was motor dysfunction of lower extremities. The spinal magnetic resonance imaging removed the possibility of spinal nerves

\begin{tabular}{|c|c|c|c|c|c|c|c|c|c|c|c|c|}
\hline \multirow[t]{2}{*}{ No } & \multirow[t]{2}{*}{ Age, $y$} & \multirow[t]{2}{*}{ Gender } & \multirow[t]{2}{*}{ Presentations } & \multirow[t]{2}{*}{$\begin{array}{l}\text { Initial Diag- } \\
\text { nosis }\end{array}$} & \multicolumn{2}{|c|}{$\begin{array}{c}\text { Initial } \\
\text { Treatment }\end{array}$} & \multirow[t]{2}{*}{$\begin{array}{l}\text { Time, } \\
\mathbf{m}\end{array}$} & \multirow[t]{2}{*}{$\begin{array}{l}\text { Anti- } \\
\text { Hu }\end{array}$} & \multirow{2}{*}{$\begin{array}{l}\text { Pathology Type } \\
\text { and Clinic Classi- } \\
\text { fications (INSS) }\end{array}$} & \multirow[t]{2}{*}{$\begin{array}{c}\text { Primary } \\
\text { Tumor Site }\end{array}$} & \multirow[t]{2}{*}{ Treatment } & \multirow[t]{2}{*}{$\begin{array}{l}\text { Follow- } \\
\text { up,y }\end{array}$} \\
\hline & & & & & G & $\mathbf{P} / \mathbf{D}$ & & & & & & \\
\hline 1 & 1.6 & M & myalgia & $\begin{array}{l}\text { polyneuropa- } \\
\text { thy }\end{array}$ & + & + & 8 & - & neuroblastoma II & $\begin{array}{l}\text { adrenal } \\
\text { glands }\end{array}$ & Chemo & 2.5 \\
\hline 2 & 3 & M & $\begin{array}{l}\text { motor dysfunc- } \\
\text { tion of both lower } \\
\text { extremities }\end{array}$ & $\begin{array}{l}\text { Guillain-Barre } \\
\text { snydrome }\end{array}$ & + & + & 2 & - & neuroblastoma III & $\begin{array}{l}\text { thoracic } \\
\text { vertebra }\end{array}$ & Chemo + radio & (0.8) relapse \\
\hline 3 & 5.2 & $\mathrm{~F}$ & cerebellar ataxia & cerebellitis & + & + & 6 & + & neuroblastoma IV & $\begin{array}{l}\text { adrenal } \\
\text { glands }\end{array}$ & Chemo + radio & 3 \\
\hline 4 & 1.7 & M & $\begin{array}{l}\text { monoplegia of the } \\
\text { lower extremity }\end{array}$ & $\begin{array}{l}\text { neurologic } \\
\text { damage }\end{array}$ & + & + & 8 & + & neuroblastoma IV & $\begin{array}{l}\text { adrenal } \\
\text { glands }\end{array}$ & Chemo + radio & 2.5 \\
\hline 5 & 5.6 & M & constipation & not clear & - & - & 2 & + & $\begin{array}{l}\text { ganglioneuroblas- } \\
\text { toma IV }\end{array}$ & $\begin{array}{l}\text { adrenal } \\
\text { glands }\end{array}$ & Chemo + radio & 2.1 \\
\hline 6 & 1.5 & $\mathrm{~F}$ & diarrhea & $\begin{array}{l}\text { Chronic diar- } \\
\text { rhea }\end{array}$ & - & - & 3 & + & $\begin{array}{l}\text { ganglioneuroblas- } \\
\text { toma IV }\end{array}$ & $\begin{array}{l}\text { adrenal } \\
\text { glands }\end{array}$ & Chemo + radio & 3.3 \\
\hline 7 & 8.5 & F & $\begin{array}{l}\text { erythema of both } \\
\text { lower extremities }\end{array}$ & $\begin{array}{l}\text { anaphylactoid } \\
\text { purpura }\end{array}$ & - & + & 0.5 & - & $\begin{array}{c}\text { ganglioneuroblas- } \\
\text { toma III }\end{array}$ & $\begin{array}{l}\text { adrenal } \\
\text { glands }\end{array}$ & Chemo & 2 \\
\hline 8 & 1.9 & M & Kawasaki disease & $\begin{array}{l}\text { Kawasaki } \\
\text { disease }\end{array}$ & + & - & 2 & - & neuroblastoma III & $\begin{array}{l}\text { adrenal } \\
\text { glands }\end{array}$ & Chemo + radio & 2 \\
\hline 9 & 2.3 & M & $\begin{array}{c}\text { thrombocytopenic } \\
\text { purpura }\end{array}$ & $\begin{array}{l}\text { thrombocyto- } \\
\text { lytc purpura }\end{array}$ & + & + & 2 & - & neuroblastoma III & $\begin{array}{l}\text { adrenal } \\
\text { glands }\end{array}$ & Chemo + radio & (0.5) dead \\
\hline
\end{tabular}

${ }^{a}$ Abbreviations: Chemo, chemotherapy; F, female; G, gammaglobulin; INSS, international neuroblastoma staging system; M, male; P/D, prednisone/ dexamethasone; Radio, radiotherapy; Time, time from onset of paraneoplstic syndrome to diagnosis of neuroblastoma. 
compression by tumor mass. Based on Fathallah opinion, PNDs are subdivided into three categories: 1 ) those whose pathogenesis is understood, 2) those that are linked to the tumor by biologic data but whose pathogenesis is not yet elucidated, and 3) those that could not be linked to the malignancy by biologic data (12). Depending on specific damage of anti-Hu antibody to neural system and characteristics of sympathetic innervation, the presenting features of neuroblastoma may be various.

Honnorat et al. has reported a child with neuroblastoma who had localized myoclonus, progressive hemiplegia and high titers of anti-Hu antibodies in the serum and cerebrospinal fluid (13), indicating that due to the widespread presence of the sympathetic nervous tissue in various body organs and apparatuses, the presenting features of neuroblastoma may be variable. We believe that these complications in our patients are paraneoplastic syndromes. Diarrhea is another well-known symptom of paraneoplastic syndrome of neuroblastoma. There is evidence that this symptom is related to vasoactive intestinal polypeptide (VIP) production in tumor cells stimulating intestinal aberrant secretions (2). This phenomenon is known as a classic endocrine tumor effect. However, constipation in association with a ganglioneurobalstoma is rare. In our study, patient 5 presented with chronic constipation which had lasted for about 6 months. In general investigation, the abdominal image revealed a tumor in his left adrenal gland. Ganglioneuroblastoma was confirmed by fine-needle biopsy. Wildhaber et al. firstly described a patient presenting with intestinal pseudoobstruction as a paraneoplastic syndrome of ganglioneurobalstoma (14). Thus, in clinical experiences, although rare, diarrhea and constipation may initially present together in cases of neuroblastoma or ganglioneuroblastoma, easily missing the diagnosis of tumor. Interestingly, we observed that patients with ganglioneuroblastoma were mostly presenting with digestive system diseases. The relationship between tumor pathology and this paraneoplastic syndrome needs further study.

Manifestations of the remaining three patients in our study were rather unusual. To our knowledge, there was no report of paraneoplastic syndrome presenting with erythema, Kawasaki disease and immune thrombocytopenic purpura, associated with immune disorders. Even though immune injury is known as the major etiology for paraneoplastic syndromes, there are no established procedures to identify it in patients with neuroblastoma prior to tumor diagnosis. These manifestations may represent new kinds of paraneoplastic syndromes. Paraneoplastic syndromes will relieve after receiving immune therapy or chemotherapy, or be cured following surgical and/or chemotherapy interventions. Currently, the exact mechanisms of immune-mediated dysfunction and endocrine tumor effect with paraneoplastic syndromes in patients are unknown. It is postulated that autoimmune disorders are the major reason, but the precise pathophyiology is unclear.
Neuroblastoma may present with a range of nonspecific neurologic symptoms in addition to the well-known OMS and cerebellar ataxia. In our series, we identified 9 out of 68 patients different kinds of paraneoplastic syndromes prior to the diagnosis of neuroblastoma. All 9 patients had an episode of misdiagnosis. To date, however, there is no identifiable common denominator among the various paraneoplastic syndromes of neuroblastoma. But in any case, the presence of unexplained neurologic manifestations and other common clinical presentations such as erythema, constipation, diarrhea, especially immune disorders in an otherwise healthy child should raise the suspicion of a possible paraneoplastic syndrome because of the presence of an undiagnosed tumor.

\section{Authors' Contributions}

Yu-tong Zhang: Dr. Zhang conceptualized and designed the study, drafted the initial manuscript, and approved the final manuscript as submitted. Jian Chang: Dr. Chang carried out the initial analyses, reviewed and revised the manuscript, and approved the final manuscript as submitted. Li-hua Feng: Dr. Feng designed the data collection instruments, and coordinated and supervised data collection, critically reviewed the manuscript, and approved the final manuscript as submitted. Zhen Zhang: Dr. Zhang designed the data collection instruments, and coordinated and supervised data collection, critically reviewed the manuscript, and approved the final manuscript as submitted. Xiao-dan Zhong: Dr. Zhong designed the data collection instruments, and coordinated and supervised data collection, critically reviewed the manuscript, and approved the final manuscript as submitted.

\section{References}

1. Sirvent N, Berard E, Chastagner P, Feillet F, Wagner K, Sommelet D. Hypothalamic dysfunction associated with neuroblastoma: evidence for a new Paraneoplastic syndrome? Med Pediatr Oncol. 2003;40(5):326-8.

2. Wildhaber B, Niggli F, Bergstrasser E, Stallmach T, Sacher P. Paraneoplastic syndromes in ganglioneuroblastoma: contrasting symptoms of constipation and diarrhoea. Eur $J$ Pediatr. 2003;162(7-8):511-3.

3. Brunklaus A, Pohl K, Zuberi SM, de Sousa C. Outcome and prognostic features in opsoclonus-myoclonus syndrome from infancy to adult life. Pediatrics. 2011;128(2):e388-94.

4. Chu CM, Rasalkar DD, Hu YJ, Cheng FW, Li CK, Chu WC. Clinical presentations and imaging findings of neuroblastoma beyond abdominal mass and a review of imaging algorithm. Br J Radiol. 2011;84(997):81-91.

5. de Buys Roessingh AS, Loriot MH, Wiesenauer C, Lallier M. Lambert-Eaton myasthenic syndrome revealing an abdominal neuroblastoma. J Pediatr Surg. 2009;44(8):E5-7.

6. Jardine DL, Krediet CP, Robinson BA. Baroreflex failure secondary to paraneoplastic encephalomyelitis in a 17 year old woman with neuroblastoma. J Neurol Neurosurg Psychiatry. 2004;75(11):1650-1.

7. Tasdemiroglu E, Patchell RA, Kryscio R. Neurological complications of childhood malignancies. Acta Neurochir (Wien). 1999;141(12):1313-21.

8. Morales La Madrid A, Rubin CM, Kohrman M, Pytel P, Cohn SL. Opsoclonus-myoclonus and anti-Hu positive limbic encephalitis in a patient with neuroblastoma. Pediatr Blood Cancer. 2012;58(3):472-4. 


\section{Zhang Yet al.}

9. Solomon GE, Chutorian AM. Opsoclonus and occult neuroblastoma. N Engl J Med.1968;279(9):475-7.

10. Blaes F. Paraneoplastic neurological syndromes--diagnosis and management. Curr Pharm Des. 2012;18(29):4518-25.

11. Polizzi A, Ruggieri M, Clover L, La Spina M, Pulvirenti A, Amyes E Vincent A, et al. A pilot study on neurological manifestations and antibodies against antigens in children with hematological and other cancers. Eur J Paediatr Neurol. 2013;17(1):97-101.

12. Fathallah-Shaykh HM. Paraneoplastic neurological syndromes: paraneoplastic or neurological? Arch Neurol.1999;56(2):151-2.

13. Honnorat J, Didelot A, Karantoni E, Ville D, Ducray F, Lambert L, Deiva K, Garcia M, Pichit P, Cavillon G, Rogemond V, DeLattre JY, Tardieu M, et al. Autoimmune limbic encephalopathy and anti-Hu antibodies in children without cancer. Neurology. 2013;80(24):2226-32.

14. Wildhaber B, Niggli F, Stallmach T, Willi U, Stauffer UG, Sacher P Intestinal pseudoobstruction as a paraneoplastic syndrome in ganglioneuroblastoma. Eur J Pediatr Surg. 2002;12(6):429-31. 